\title{
COVID-19 in the Central Asian Region: National Responses and Regional Implications
}

\section{Gregory Gleason ${ }^{1}$ and Kuralay Baizakova ${ }^{2}$}

1 George C. Marshall European Center for International Security Studies, https://www.marshallcenter.org/

2 Al-Farabi Kazakh National University, Almaty, Kazakhstan, https://www.kaznu.kz/en

\begin{abstract}
Soon after the first instance of COVID-19 in Central Asia was recorded in March 2020 in Kazakhstan, the government took immediate steps to introduce containment and mitigation measures. As cases of COVID-19 appeared soon afterwards in Uzbekistan, Kyrgyzstan, and later in Tajikistan, the governments swiftly responded, instituting emergency measures, empowering law enforcement and medical authorities to implement a broad range of counter-infection mitigation measures to protect public health. Cross-border travel restrictions were imposed. Lockdowns and sheltering-in-place restrictions were imposed in most major cities and curfews were enforced. Routine commercial air flights were canceled or significantly reduced in international and many domestic airports. New levels of visa restrictions were implemented in all the Central Asian countries. The initial infection containment measures were highly successful in curtailing the early spread of Covid-19. But governments immediately confronted a broad range of social and economic difficulties brought on by Covid-19. The sudden interruption of typical earnings and livelihoods for many people, the disruption of commercial supply chains, the cratering of commodity prices and, for Kyrgyzstan and Tajikistan in particular, the loss of migrant labor opportunities and remittances, combined with other consequences of Covid-19 to produce a region-wide economic catastrophe. The pandemic called for immediate steps on the part of all governments in the region and focused attention on addressing the long-term social, economic, and even regional political implications.
\end{abstract}

Keywords: Central Asia, COVID-19, economic crisis, regional security. 
SARS-CoV-2, the virus which is responsible for the COVID-19 disease, emerged in China in late 2019 and in early 2020 began appearing in countries around the world. The Central Asian countries-Kazakhstan, Kyrgyzstan, Tajikistan, Turkmenistan, and Uzbekistan - lie midway between China and many of its trading partners in Europe and the Middle East. COVID-19 was first recognized in Kazakhstan in March 2020, and after that in Uzbekistan, Kyrgyzstan, ${ }^{1}$ and later in Tajikistan. ${ }^{2}$ The effects of COVID-19 were soon recognized in Turkmenistan. ${ }^{3}$ During this period, COVID-19 was also spreading in the Central Asian bordering countries of Afghanistan, Iran, and Russia.

While Covid-19 challenges all societies and all countries in the same way, countries have various and, sometimes, importantly different circumstances. Some unique conditions put individual countries in a comparative advantage, and some put them at a disadvantage. ${ }^{4}$ In all cases, whatever the pluses or minuses of particular situations, all governments must provide three categories of responses. The first is the emergency medical response; it is directed at containing the spread of the disease. The second is devoted to the mitigation of the effects of the disease, particularly the social and economic consequences. The third category is concerned with the long-term or structural adaptation to the consequences, the medical, social, and economic effects of the pandemic.

\section{Emergency Measures - Front Line in the Pandemic}

At the end of 2019, Central Asian governments were actively pursuing policies designed to expand economic ties, social relationships, tourism, and other forms

1 Gregory Gleason and Anna Gussarova, “Covid-19's Long-term Implications for Central Eurasia," Diplomatic Courier, May 6, 2020, https://www.diplomaticourier.com/posts/ covid-19s-long-term-implications-for-central-eurasia.

2 Catherine Putz, "Where Are There Still No COVID-19 Cases? An Updated Analysis," The Diplomat, May 6, 2020, https://thediplomat.com/2020/05/where-are-there-still-nocovid-19-cases-an-updated-analysis.

3 Turkmenistan authorities avoided not only formal announcements about Covid-19 but prevented Turkmenistan press and media agencies from any reference to the disease. However, the Turkmenistan president did take part in an unusual video discussion of four Central Asian state leaders on April 9, 2020. The Turkmenistan leader joined the others in pledging a new level of regional cooperation in combatting Covid-19 in Central Asia. See "Kasym-Zhomart Tokayev Called the Heads of Turkic-Speaking Countries to Join in Countering the Current Global Crisis," KAZINFORM, April 10, 2020, in Russian, https://www.inform.kz/ru/kasym-zhomart-tokaev-prizval-glav-tyurko yazychnyh-gosudarstv-ob-edinit-sya-dlya-preodoleniya-nyneshnego-global-nogokrizisa_a3636537. A statement of the Turkmen President has been at times available on the Turkmen government website http://www.turkmenistan.gov.tm/?id=20713.

4 While the countries of the region are often grouped together as "Central Asia," there are in fact significant differences in political practice and political culture in the region. Many of these differences are illustrated in the differing journalistic coverage of the international media such as Eurasianet (https://eurasianet.org/dashboard-corona virus-in-eurasia), Radio Free Europe/ Radio Liberty (https://www.rferl.org/a/thespread-of-the-coronavirus/30401889.html) and Sputnik (https://sputniknews.com/). 
of cross-border relationships on a region-wide basis. Cross-border traffic in all five Central Asian states was running at a high level. Economic policies were producing good results throughout Central Asia. Uzbekistan, in particular, poised by presidential succession in 2016 and focused on policies geared to greater foreign economic activity, was in the midst of a highly successful economic reform, increasingly linking Uzbekistan with its neighbors and with the outside world. World Bank Vice President Cyril Muller, who headed the European and Central Asian region, noted in January 2020 that "Uzbekistan's lending program is now the second largest in the region." In a short period, Uzbekistan had moved from a relatively isolated country to the position of maintaining the largest World Bank portfolio among post-communist countries. ${ }^{5}$

The announcement on December 31, 2019 on the appearance of what was apparently a mysterious outbreak of pneumonia in the Hubei province of China caused little alarm in the Central Asian states. Central Asian medical and law enforcement authorities tracked the announcements from Chinese medical authorities. Central Asian politicians responded very cautiously, suggesting a concern to avoid exaggerating risks to public health, which might ignite unjustified anxieties.

Central Asian authorities had recent relevant experience with the control of virus infection. In early 2003, an outbreak of the severe acute respiratory syndrome (SARS) in China was identified by Chinese medical authorities. In a period of months, the 2003 SARS virus outbreak spread to at least two dozen countries. Over a period of 18 months, the SARS outbreak infected more than 8,000 people, resulting in somewhat fewer than 800 deaths. Because Central Asian political and medical authorities instituted prompt and highly effective counter-infection policies, no cases of SARS were reported in any of the Central Asian countries. So, when news of a new SARS outbreak surfaced in late 2019 and began to grow in early 2020, Central Asian medical authorities were relaxed in the assumption that their anti-infection measures were adequate.

But the virus which appeared in 2019 was new, highly infectious and very dangerous. ${ }^{6}$ Reports of the spread of the virus were issued by the World Health

5 The World Bank defines the European and Central Asian region as including Albania, Armenia, Azerbaijan, Belarus, Bosnia \& Herzegovina, Bulgaria, Croatia, Georgia, Kazakhstan, Kosovo, Kyrgyz Republic, Moldova, North Macedonia, Montenegro, Poland, Romania, Russian Federation, Serbia, Tajikistan, Turkey, Turkmenistan, Ukraine, and Uzbekistan - a group of countries which includes basically all the states of the post-communist world. Turkey, of course, was never a communist country and most institutions do not categorize Turkey today as either in "Europe" or in "Central Asia." The World Bank, "Uzbekistan Enters the Next Phase of Market Reforms with Renewed Support from the World Bank," January 18, 2020, www.worldbank.org/ en/news/press-release/2020/01/18/uzbekistan-enters-next-phase-of-marketreforms-with-renewed-support-from-world-bank.

6 SARS-CoV-1 and SARS-CoV-2 are related but different viruses and produce different infections. SARS (Severe Acute Respiratory Syndrome), WHO, https://www.who.int/ ith/diseases/sars/en. 
Organization (WHO). As the infection spread to China's bordering countries and the epidemic proportions grew, the reality of the threat in Central Asia became apparent. Tajik and Turkmen authorities, while denying that there was a problem, began preventative steps even without public announcements. Borders were abruptly closed for reasons of which the public was not aware. ${ }^{7}$ Observers witnessed actions indicating the spread of the epidemic without any public acknowledgment. ${ }^{8}$ Statements of some leaders appeared to be shifting blame to other countries. ${ }^{9}$ The spread of the infection was unprecedented, but the spread of information in the new digital information space was even more unprecedented than the epidemic itself. The public seemed to be circulating information about infection even when government authorities were denying it. ${ }^{10}$

COVID-19 spread throughout the Central Asian region in the early months of 2020, provoking timely and effective government measures in each of the five Central Asian countries. The containment measures were focused on large cities. Cross-border travel restrictions were backed up by urban lockdowns, curfews, and sheltering-in-place restrictions. Commercial air flights were restricted. Traffic and freight in major areas drew to a standstill. Visa restrictions were implemented, and personal identification was required for movement within cities. Stores were shuttered and public institutions were closed. Disruption of social and economic life as a consequence of physical distancing and contact tracing was almost immediately apparent. As governments around the world closed or substantially curtailed cross border traffic and freight, the prices for many internationally traded products took a sudden and steep downturn. The fall in primary commodity prices put Central Asian exporters in a precarious position. The disruption of supply chains of trade and transportation throughout the Central Asian region was significant beyond any measure for which the Central Asian political and economic authorities were prepared.

Table 1 includes data reported by the governments to the World Health Organization and contained in the WHO Situation Report. The data is listed from the period of the first identification of Covid-19 in the Central Asian states (March 15, 2020) and includes the data reported after 45 days (May 1, 2020).

7 Farangis Najibullah, "Tajik Workers Face Dire Future as Russia Closes Borders Over Coronavirus," Radio Free Europe/ Radio Liberty, March 18, 2020, www.rferl.org/a/ tajik-workers-face-dire-future-as-russia-closes-borders-overcoronavirus/30495815.html.

8 Nathan Paul Southern and Lindsey Kennedy, "Central Asian States Can't Hide the Coronavirus Any Longer. Authoritarian States Have Been Downplaying Numbers. That Won't Last," Foreign Policy, March 20, 2020, https://foreignpolicy.com/2020/03/20/ central-asian-states-cant-hide-coronavirus-kazakhstan-uzbekistan-kyrgyzstantajikistan-turkmenistan.

9 Andrea Schmitz, "Someone Else's Virus," SWP Comment, March 27, 2020, www.swpberlin.org/en/publication/someone-elses-virus.

10 Farangis Najibullah, "Despite Zero Reported Cases, Coronavirus on Everyone's Mind in Tajikistan," Radio Free Europe/ Radio Liberty, April 3, 2020, www.rferl.org/a/despitezero-reported-cases-coronavirus-on-everyone-s-mind-in-tajikistan/30527299.html. 
The data includes the number of cases, recent infections, and deaths attributed to Covid-19. The WHO data clearly indicates that the governments of the Central Asian states, by all comparative standards, should be given high marks with respect to their actions to contain the spread of the SARS virus in the initial period. The spread of the infection was significantly hindered by the measures enacted.

Initial containment steps can flatten the dispersion curve by limiting the initial spread, but long-term containment grows more difficult as the numbers of infected victims are larger and new infections appear from foreign sources. Subsequent WHO data indicates spikes, particularly in Kyrgyzstan. Russian Federation's Ministry of Health emergency website "Stopkoronovirus" (in the Russian language) presents daily information on the spread of Covid-19 in the Russian Federation. The data attest to the rapid rise of the virus. ${ }^{11}$ Central Asia's other bordering countries are facing a rising threat from Covid-19. In a section entitled "Covid-19 Strikes Afghanistan," the most recent SIGAR Report noted: "Afghanistan's numerous and, in some cases, unique vulnerabilities-a weak health-care system, widespread malnutrition, porous borders, massive internal displacement, contiguity with Iran, and ongoing conflict-make it likely the country will confront a health disaster in the coming months." 12

The medical emergency in the Central Asian states is not yet over. It may continue for some period and the specific length of that period may not be knowable for some time. In the present period of the infection, attention must turn to the second category - the mid-term problems and effects. This is the stage in which the countries of Central Asia, individually and collectively, must come to grips with the challenges of disruption to the social and political order brought about by Covid-19. The steps Central Asian government take will have long-term implications for the social, economic, and even political future of the states and the region. This Covid-19 pandemic will require close collaboration between the civilian political authorities and the national security institutions in the Central Asian region.

SARS-CoV-2 is not a static opponent. It is also not a strategic opponent. In strategic interactions, the opponent is making decisions based on continually adjusting calculations. ${ }^{13}$ In strategic interactions, parties make adjustments based on expectations. In many strategic interactions, deception is an important mode of operation, sometimes feigning and sometimes challenging. Bravado and dissimulation may be useful instruments in strategic posturing. But SARS-CoV-2 is not a calculating opponent. Viruses are conditions-dependent and do not change

11 Russian Ministry of Health, "Stopkoronovirus," https://xn--80aesfpebagmfblc0a.xn-p1ai.

12 Special Inspector General for Afghanistan Reconstruction (SIGAR), Quarterly Report to the United States Congress, April 30, 2020, p. 14, https://www.sigar.mil/pdf/quarterly reports/2020-04-30qr-intro-section1.pdf.

13 Building on the insights of Thucydides, the classic work of the logic of strategic theory is Bruce Bueno de Mesquita, The War Trap (New Haven \& London: Yale University Press, 1981) 
Table 1. Reported cases in the Central Asian States to WHO in the initial 45 days of Covid-19.

\begin{tabular}{|lcccc|c|}
\hline Country & $\begin{array}{c}\text { Date of } \\
\text { first } \\
\text { Covid-19 } \\
\text { report }\end{array}$ & $\begin{array}{c}\text { Cases } \\
\text { (1 May } \\
2020)\end{array}$ & $\begin{array}{c}\text { Deaths } \\
\text { (1 May } \\
2020)\end{array}$ & $\begin{array}{c}\text { Population } \\
\text { (million) }\end{array}$ & $\begin{array}{c}\text { Territory } \\
\text { Square kilo- } \\
\text { meters }\end{array}$ \\
\hline Kazakhstan & $\begin{array}{c}15 \text { March } \\
2020\end{array}$ & 3551 & 25 & 18.5 & $2,724,900$ \\
\hline Kyrgyzstan & $\begin{array}{c}19 \text { March } \\
2020\end{array}$ & 756 & 8 & 6.5 & 199,951 \\
\hline Tajikistan & $\begin{array}{c}1 \text { May } \\
2020\end{array}$ & 15 & 0 & 9.2 & 143,100 \\
\hline Turkmenistan & $\begin{array}{c}\text { None re- } \\
\text { ported }\end{array}$ & 0 & 0 & 5.9 & 491,210 \\
\hline Uzbekistan & $\begin{array}{c}16 \text { March } \\
2020\end{array}$ & 2046 & 9 & 33.5 & 448,978 \\
\hline
\end{tabular}

Source: Covid-19 figures are collected by national authorities and reported to WHO Situation Report. ${ }^{14}$ Population figures are from the Population Reference Bureau, mid-2019 totals. ${ }^{15}$ The reported Covid-19 infection figures differ substantially in some instances from the figures estimated by other sources. Compare, for instance, the figures listed by the COVID-19 Dashboard by the Center for Systems Science and Engineering (CSSE) at Johns Hopkins. ${ }^{16}$

their own conditions. In combatting condition-dependent virus infections, no strategic posture is useful unless it is attuned to eliminating or mitigating the conditions which provide opportunities to the virus. Eliminating the conditions in which the virus prospers is the first principle in combatting the virus. There are other factors that can accelerate the retreat of the virus, but invective and rhetorical haranguing is not among them. Effective measures are only those that are specifically shaped and implemented to combat the objective threats.

\section{From Containment to Mitigation and Recovery}

In the first two months of the pandemic, the Central Asian governments took swift and effective measures to stem the further spread of the Covid-19 infection. However, given the collapse in commodity prices, the disruption of commercial supply chains, the sudden shift in migrant labor and remittances, the cessation of typical earnings and livelihoods, and the collateral effects of the pan-

14 WHO, "Coronavirus Disease (COVID-2019) Situation Reports," https://www.who.int/ emergencies/diseases/novel-coronavirus-2019/situation-reports.

15 Population Reference Bureau. For data, see: https://www.prb.org.

16 Johns Hopkins University, "Corona Virus Map," https://coronavirus.jhu.edu/ map.html. 
demic have created an unprecedented social and economic crisis in Central Asia. Social and economic upheaval at this level unavoidably entails political effects.

In an interview in Bishkek, Azamat Temirkulov, a Kyrgyz scholar, summarized the crisis in Kyrgyzstan, pointing out that "enterprises will solve their difficulties through job cuts, some will close due to lack of profit, others will completely go bankrupt. Our migrant workers will begin to return home, joining the ranks of the army of unemployed Kyrgyzstan." Temirkulov noted that "We are in a nonstandard situation; this is not another cyclical crisis, which means that the measures applied must also include non-standard solutions." 17

The predominant political culture of Central Asian societies, at least in comparison with western societies, is focused on social cohesion. Many aspects of current social and economic conditions in Central Asia would appear to indicate high levels of vulnerability to a contagious disease. Central Asian societies differ to a certain extent by region, but in general social relations throughout Central Asian societies can be described as highly family-oriented, social, congregated in densely populated villages and cities and with family-maintained elderly populations. Conditions of diabetes and high blood pressure, as well as other chronic conditions associated with vulnerability to Covid-19, are relatively widespread. Large numbers of people in the Central Asian countries are self-employed or work in positions in the informal economy. Many of these people are not legally entitled to the socio-economic protections that are accorded to officially employed persons.

The International Labor Organization, for instance, estimated that as many as 75 percents of those employed in Tajikistan were in the informal sector. Data on informal sector employment may be unreliable and the other Central Asian countries could be expected to have a smaller informal sector in comparison, but the effects of the disruption of employment exerted by the pandemic conditions can only be regarded as severe. ${ }^{18}$ Perhaps more importantly, large numbers of migrant workers, particularly from Tajikistan and Kyrgyzstan, have held labor positions abroad, mainly in the Russian Federation. There were also large numbers of migrant workers from Uzbekistan working in South Korea. The economic role of these labor migration patterns is substantial. As much as 50 percent of the national GDP of Kyrgyzstan was estimated by a UNDP study to result from Kyrgyz remittances. ${ }^{19}$ For up-to-date data on remittance flows between the Russian Federation and Tajikistan, see the World Bank's roster on remittance flows

17 Azamat Temirulov, "The Pandemic is a Chance to Reform the Kyrgyz Economy," Vechernyi Bishkek, April 13, 2020, in Russian, https://www.vb.kg/doc/387130_azamat_ temirkylov:_pandemiia_eto_shans_perestroit_ekonomiky_kr.html.

18 World Employment and Social Outlook, Trends 2019 (Geneva: International Labor Organization, 2019), p. 53, https://www.ilo.org/wcmsp5/groups/public/---dgreports/--dcomm/---publ/documents/publication/wcms_670542.pdf.

19 Labour Migration, Remittances, and Human Development in Central Asia, Central Asia Human Development Series (UNDP, 2015): p. 8, https://www.undp.org/content/dam/ rbec/docs/CAM\&RHDpaperFINAL.pdf. 
around the world. ${ }^{20}$ The effects of the pandemic in both economic and political terms are massive. ${ }^{21}$

\section{Long-term Policies of Adjustment and Recovery}

The choices made now by the political leadership in the Central Asian countries on how to deal with the long-term consequences of the pandemic will shape the geopolitical future of the Central Asian states. The Central Asian states, particularly Kazakhstan and Uzbekistan, have carried out in the short-term highly effective public policy measures to meet the first phase of the medical emergency. The medium-term problems of addressing the downward-spiraling social and economic conditions and the policies needed to address them in the months and years ahead will be the focus of forthcoming government activity. In the Central Asian countries, law enforcement, the military, and other security organizations have been assigned to the initial tasks at hand, but as more difficult questions such as very large-scale unemployment begin to exert pressures on local and national leaders, their tasks can be expected to become even more challenging.

The vast increase in government outlays for public emergency support and the downward spiraling drop in government revenue due to tax shortfalls have already exhausted most treasury funds in the Central Asia countries - with Kazakhstan being the sole exception. It may be expected that, fiscally, none of the Central Asian governments can endure for a prolonged period these levels of outlays and constrained revenues without additional financial sources. Central Asian governments will need to address the pressures of structural adjustment on a scale never even contemplated before. Self-generated "bailout" programs in the Central Asian states may be able to meet the requirements for a certain time, but the inability of the governments to finance such massive shortfalls over a prolonged period without running the risk of runaway inflation makes foreign assistance inevitable.

The major international financial institutions have lined-up to offer aid. IMF Managing Director Kristalina Georgieva described the scope and scale of the pandemic challenge bluntly: "Covid-19 has disrupted our social and economic order at lightning speed and on a scale that we have not seen in living memory." 22 The main lending institutions have stepped forward. The World Bank is in the process of developing new forms of emergency funding programs. ${ }^{23}$ All the traditional

20 The World Bank, "Remittance Prices Worldwide: Making Markets More Transparent," https://remittanceprices.worldbank.org/en/corridor/Russia/Tajikistan.

21 Catherine Putz, "Remittances to South and Central Asia Poised to Dive Dramatically," The Diplomat, May 05, 2020, https://thediplomat.com/2020/05/remittances-tosouth-and-central-asia-poised-to-dive-dramatically.

22 Kristalina Georgieva, "Confronting the Crisis: Priorities for the Global Economy," IMF, April 9, 2020, www.imf.org/en/News/Articles/2020/04/07/sp040920-SMs2020Curtain-Raiser.

23 The World Bank, "World Bank Group and Covid-19 (coronavirus)," https://www.world bank.org/en/who-we-are/news/coronavirus-covid19. 
regional development banks such as the Asian Development Bank and even the new regional banks such as the Eurasian Development Bank and the Asian Infrastructure Investment Bank have pledged to raise new forms of support to meet the challenges. But the traditional assistance organizations provide either limited grants or long-term lending programs. Neither of these traditional mechanisms is expected to cover the costs of supporting the governments of the Central Asian states in the long term. International financial donor institutions are designed to help countries negotiate "bumps in the road"; they are not designed to provide all the resources for situations in which all the vehicles are at a standstill and all the roads are closed. ${ }^{24}$

The wealthy countries of Europe, the Middle East, and North America are in a similar situation with respect to the fiscal challenges, but the specific set of options is very different. Due to the severity of the economic disruption caused by the pandemic, the central financial authorities in the developed countries have turned to instruments of a scope and scale never used before. In Europe, the European Stability Mechanism (ESM) in April 2020 agreed to institute three safety net measures for workers, businesses, and governments, amounting to a package worth $€ 540$ billion. On April 23, 2020, the EU Heads of State of Government (European Council) endorsed the agreement. ${ }^{25}$ In the United States, the Coronavirus Aid, Relief, and Economic Security (CARES) Act was passed by Congress and signed into law on March 27th, 2020. This provided for over $\$ 2$ trillion economic relief package with funding for individuals, workers, companies, and local governments. The goal of this legislation is to prevent the economy as a whole from grinding to a halt by making sure that individuals have support, companies can continue to run, and governments continue to function. ${ }^{26}$

These financial programs are new, but even the sources of funding for these programs represent innovative approaches to public finance. The US Federal Reserve, which functions as the US central bank, began using unconventional instruments amid the 2008 financial crisis in order to promote the circulation of money. The U.S. began retreating from this kind of programs, but the pandemic crisis made it necessary to return to innovative fiscal programs. In the conventional market economy textbook, the creation by fiat of new fiscal resources raises many questions. If money is not earned or borrowed, where does it come from? Simply "printing money" to cover unpaid obligations is not a panacea. To do that would cause inflation. However, the volume of money in circulation is only one factor, along with the amount of circulation and availability of the

24 Gregory Gleason, "Post-Pandemic Central Asia: Moving Beyond 'Helicopter Money'," The Diplomat, May 20, 2020, https://thediplomat.com/2020/05/post-pandemiccentral-asia-moving-beyond-helicopter-money.

25 "European Stability Mechanism (ESM) Pandemic Crisis Support," https://www.esm. europa.eu/content/europe-response-corona-crisis.

26 Kelsey Snell, "What's Inside The Senate's \$2 Trillion Coronavirus Aid Package," NPR, March 26, 2020, https://www.npr.org/2020/03/26/821457551/whats-inside-thesenate-s-2-trillion-coronavirus-aid-package. 
money. In order to accelerate the use of money while increasing its availability (liquidity), new fiscal approaches have produced emergency funds at levels never before even contemplated. The US Federal Reserve adopted a policy of purchasing bonds and equities on the open market and then re-selling them in order to circulate financial resources. The European Central Bank has followed a similar course of action in Europe.

This course is not available to the Central Asian governments because they are dependent on earnings from exports (such as the revenue deriving from Kazakhstan's oil exports) and reliant upon foreign currencies to fund the purchase of imports from other countries, such as China. If Central Asian central banks simply begin "printing" more of their national currencies in order to pay bills, this will lead directly to inflation. The Central Asian financial managers are all familiar with the bitter experience of the years 1992-1994 when their countries were flooded with Rubles, the value of which they could not control. This led to calamitous circumstances where people lost their entire life savings when they relied upon banks to protect their savings. This is a situation all too vivid in the recollection of many Central Asians. The government financial managers in the Central Asian countries will need, at least in part, to look to the outside world for solutions to the problems caused by the pandemic.

\section{Regional Security Implications of the SARS Pandemic}

In just the first few short months of 2020, the world has witnessed a fundamental transformation in the global order, in social, economic, and even geopolitical respects. As David Ignatius summarized, COVID-19 challenges defense analysts to begin assessing how the global spread of this deadly disease is a catalyst in changing the ways we think about peace, prosperity, and warfare. ${ }^{27}$ To a certain extent, any crisis with the severity of this pandemic is a test of the state's mettle. States and political leaders will be judged by their responses. The Central Asian response to the first stage of the pandemic will be illustrative. Prompt and effective action, as we have seen, deserves credit for protecting public health. But the long-term consequences are more of a challenge. The "top-down," quasi-authoritarian response will be questioned by the proposition that a "free and open society is in fact best positioned to deal with a crisis that demands factual, evidence-based strategic-policy decisions. ${ }^{28}$ Even if the SARS-CoV-2 virus attenuates, either in waves or suddenly disappearing, enduring consequences of the disruption are inevitable and will have consequences. As Marlene Laruelle and

27 David Ignatius, "The Coronavirus Is Already Reshaping Defense Strategies," The Washington Post, April 9, 2020, https://www.washingtonpost.com/opinions/howthe-coronavirus-is-changing-how-we-think-about-warfare/2020/04/09/7756d3307a9f-11ea-a130-df573469f094_story.html.

28 Haroro J. Ingram, "Pandemic Propaganda and the Global Democracy Crisis," War on the Rocks, May 18, 2020, https://warontherocks.com/2020/05/pandemic-propa ganda-and-the-global-democracy-crisis. 
Madeline McCann noted, "the state's ability to present itself as having effectively managed the crisis could have deep political impacts." 29

The major international financial institutions have lined-up to offer aid to the Central Asian states, but the scale and scope of the assistance are not likely to be sufficient to stabilize the economic consequences in the long-term. Outside emergency help is necessary. But nothing is free, especially money. Altruism is not boundless. Foreign institutions, reflecting interests of their principal stakeholders in Beijing, Moscow, or Washington, will seek to gain influence in the decisions which beneficiaries make. If outside help comes with strings attached, it is important to ask what the conditions will be.

For all the reasons articulated above, the Central Asian region in 2019 was marked by signs of significant progress. Political succession took place in 2019 in Kazakhstan, marred by some criticism of less than fully inclusive democratic participation in the decision-making process, but the economy was growing strongly. Kyrgyzstan was negotiating new forms of trade and borrowing arrangements with its northern "Patron," Russia. Large numbers of Kyrgyz workers in Russia were widely considered to be a reliable form of mutual interdependence. Tajikistan was economically growing slowly but positively, with expectations of a political succession that would retain rule within the President's large family. Turkmenistan was investing in greater export potential for its hydrocarbon riches. Uzbekistan was well on the path to the first real economic transformation, price liberalization, and privatization of many state assets. In would be an exaggeration to state that public support for Central Asian governments was unanimous within the societies, but it would not be an exaggeration to say that by far the largest proportion of the population favored continued improvement in what was regarded as the status-quo. COVID-19 changed this abruptly and significantly.

What are the implications with respect to the SARS-Cov-2 attack upon the Central Asian status-quo? The foreign policy of each of the Central Asian states will be influenced by COVID-19, even if the virus soon attenuates or fully disappears. The shifts in relations brought about by the collapse of the world trading order and the intermediary position of the Central Asian states can be expected to permanently affect the relations among states. The states had very different foreign policy postures when the pandemic emerged. Kazakhstan's foreign policy strategists in the new capital of Nur-Sultan emphasize the country's multivector foreign policy, which enabled them to retain good economic relations with both Moscow and Beijing, without becoming too politically dependent on either. The buoyant hydrocarbon trade was carried forward by Russian, Saudi and other major producers but pulled along Kazakhstan as a beneficiary. Kazakhstan's formula was successful and would eventually, analysts contended, allow

29 Marlene Laruelle and Madeline McCann, "Post-Soviet State Responses to COVID-19: Making or Breaking Authoritarianism?" PONARS Eurasia, Policy memo 641, March 2020, http://www.ponarseurasia.org/memo/post-soviet-state-responses-covid-19making-or-breaking-authoritarianism. 
them to bring the country's vast resource riches into play in a diversified economy, fueled as much by digital technologies as by oil.

Uzbekistan's foreign policy strategists threw their hat into the ring starting in 2016 to agree to fundamental structural changes in their economy in order to open up to foreign imports and seek export opportunities. The election of the new president in December 2016 brought a new direction to the development of the "Uzbek Path," a process that grew in momentum through the following years. By 2020, Uzbek foreign policy was increasingly robust and oriented on international partnerships in all directions based on equal standing. For the first time since the disintegration of the USSR, Uzbekistan's foreign policy posture was characterized by good and improving economic, social, and political relations with all states in the Central Asia region and with harmonious relations with Beijing and Moscow.

The foreign policy postures of Kyrgyzstan and Tajikistan were less auspicious. The two countries were similar with respect to a number of constraining features. Each of the countries is mountainous, with limited urban development and agriculture and husbandry limited by the seasons and availability of arable land. Both countries are divided by major mountain ranges into a north and south section, with Kyrgyzstan's capital lying in the northern part of the country and Tajikistan's capital lying in the southern part of the country. Divisions between north and south are magnified by strong regional divisions with different cultural foundations and even languages. Both countries are net energy importers because they have virtually no hydrocarbon reserves, although both countries are rich in hydropower potential. Both countries are situated geographically on the outskirts of established trading corridors. Economic development levels were among the lowest of the post-Soviet states. In the decade before 2020, both Kyrgyzstan and Tajikistan grew increasingly reliant upon Moscow and Beijing for financing and market access.

Kyrgyzstan and Tajikistan could be contrasted with Turkmenistan, possessing none of its advantages but sharing its limitations. Hydrocarbon-rich Turkmenistan developed a foreign policy it called "positive neutrality." This distinctive foreign policy was designed to allow Turkmenistan to develop its vast natural gas resources and, at the same time, remain aloof from diplomatic contretemps. Uniqueness grew to be a defining feature of the country's policy posture on all issues other than foreign gas exports. Diversification of the hydrocarbon economy was never even considered as a government policy objective.

The sudden cessation of the functioning of the global trade system has thrown into question the foreign policy priorities of the Central Asian states. The seriousness of the disruption could thrust states in the direction of greater reliance on common regional objectives and, on the other hand, could also speed up development courses in which they find a common interest with outside patrons, whether Moscow, Beijing, or even New Delhi.

Some analysts look forward to identifying the political implications in the Eurasian space that follow from the disruption caused by the pandemic. Eurasian 
"integrationists" see the pandemic as making close economic and political ties in the region more important than ever. Russian Prime Minister Mikhail Mishustin (before he was stricken by the coronavirus himself) argued in a video conference with Central Asian leaders on April 10, 2020, that the "mechanisms of the Eurasian Economic Union have already proven their effectiveness." Mishustin asserted: "Our countries are working together, clearly and coherently, to jointly confront the common threat." ${ }^{30}$ Nikita Mendkovich, an advocate of closer ties between Moscow and the Central Asian capitals, warned that disruption of markets would result in significant food shortages in the Central Asian states unless the Eurasian Economic Union is empowered to restore supply chains throughout the region. ${ }^{31}$

The "Eurasian" northward-oriented institutions are apt to encounter some competition from the "Asian" eastward-oriented institutions. Offers of concessional terms of infrastructure development included in many of the proposals of Beijing's "Bridge and Road Initiative" (BRI) may attract increasing attention in Central Asian capitals as a result of the trade and supply chain catastrophe. The post-pandemic situation is more complicated, but as Arne Elias Corneliussen observed, "Covid-19 does not change China's underlying strategic rationale for the BRI." 32

As the competition between the emerging vectors of foreign assistance and foreign influence is resolved, bureaucratic disputes about priorities and order of operations may increasingly be crowded out by disputes over intrusions impinging on national sovereignty. These differences of view may be not only problems of coordination but may result in competition over jurisdiction. Kyrgyzstan and Tajikistan, in particular, face dire economic circumstances as a result of the pandemic. The borders among the Central Asian countries, particularly in the Fergana Valley region, were very much the product of political choices made long ago by foreign political authorities. The coronavirus pandemic threatens to push the Fergana Valley countries into a situation where only a condominium with neighbors is possible - a condominium that can protect their societies even if not their national sovereignty.

30 "The Mechanisms of the EAEU Demonstrate their Effectiveness-Mishustin on the Struggle with COVID," Sputnik, April 10, 2020, in Russian, https://ru.sputnik.kg/ politics/20200410/1047808934/mishustin-eaehs-mekhanizmy-kachestvo.html.

31 Nikita Mendkovich, "The Pandemic Has Already Unleashed the 'Hunger Spiral', Severing the Food Supply Chain," Sputnik, April 8, 2020, in Russian, https://tj.sputniknews.ru/economy/20200409/1031039737/evraziyskoesoobschestvo-koronavirus.html.

32 "International online discussion with IWPR: COVID-19 and the Chinese BRI in Central Asia," Central Asia Bureau for Analytical Reporting, April 24, 2020, https://cabar.asia/en/international-online-discussion-with-iwpr-covid-19-and-thechinese-bri-in-central-asia. 


\section{Disclaimer}

The views expressed are solely those of the authors and do not represent official views of the PfP Consortium of Defense Academies and Security Studies Institutes, participating organizations, or the Consortium's editors.

\section{Acknowledgment}

Connections: The Quarterly Journal, Vol. 19, 2020 is supported by the United States government.

\section{About the Authors}

Gregory Gleason is a Professor of Security Studies at the George C. Marshall European Center for Security Studies. The Marshall Center is a partnership between the German Ministry of Defense and the U.S. Department of Defense. During 2018-2019, while on leave from the Marshall Center, Gleason served as the U.S. Ministry of Defense Adviser in Uzbekistan, assigned to the Uzbek Armed Forces Academy. Before joining the Marshall Center in 2007, Gleason taught courses in international relations and public affairs. Gleason retired from the University of New Mexico, where he is Professor Emeritus.

Kuralay Baizakova is a Professor of International Relations and World Economy at al-Farabi Kazakh National University, Almaty, Kazakhstan, and Director of its Institute for Security Issues and Cooperation. Her research interests include international security, regional security, security cooperation, regional integration, and European integration. Dr. Baizakova is an Alumna of the George C. Marshall Center and the author of the more than 300 scientific publications. 